\title{
Design and study of anticaries effect of different medicinal plants against S.mutans glucosyltransferase
}

Kiranmai Mandava 1*, Uma Rajeswari Batchu², Shravya Kakulavaram', Shulamithi Repally', Ishwarya Chennuri', Srinivas Bedarakota ${ }^{1}$ and Namratha Sunkara ${ }^{1}$

\begin{abstract}
Background: The present study was aimed to evaluate the molecular level anticaries effect of different medicinal plants against Streptococcus mutans (S.mutans) glucosyltransferases (gtf).

Methods: A total of six natural sources named as Terminalia chebula (T.chebula), Psidium guajava (P.guajava), Azadirachta indica (A.indica) and Pongamia pinnata (P.pinnata); two essential oils, clove (Syzygium aromaticum) and peppermint oil (Mentha piperita) were selected as test samples. Hydroalcoholic plant extracts and essential oils were examined for their inhibitory potential on $\mathrm{gtf}$ isolated from S.mutans. Polyherbal mouth wash was prepared and its effect on gtf activity was compared with commercial chlorhexidine mouth wash $(5 \% \mathrm{w} / \mathrm{v})$. Enzyme kinetic study was carried out in order to explore the molecular mechanism of enzyme action.

Results: Out of six natural sources tested, A.indica has shown maximum inhibitory effect of 91.647\% on gtf and T.chebula has shown $\mathrm{IC}_{50}$ of $1.091 \mathrm{mg} / \mathrm{ml}$ which is significant when compared to standard chlorhexidine. From the final result of kinetic analysis it was found that T.chebula, P.guajava and P.pinnata have show uncompetitive inhibition where as A.indica has shown non-competitive inhibition. Surprisingly, both essential oils have shown allosteric inhibition (sigmoidal response). The polyherbal moutwash has shown significant inhibitory potential on gtf (95.936\%) when compared to commercial chlorhexidine mouthwash $(p<0.05)$.

Conclusion: All the tested samples have shown considerable gtf inhibitory action. Moreover polyherbal mouth wash has shown promising noncompetitive inhibitory activity against gtf and it could be the future formulation to combat dental caries.
\end{abstract}

Keywords: S.mutans, Glucosyltransferase, Azadirachta indica, Terminalia chebula, Polyherbal mouth wash, Anticaries agent

\section{Introduction}

Fermentation of carbohydrates presents in a food by oral bacteria results in a decrease in the $\mathrm{pH}$ of plaque and demineralization of enamel and finally formation of dental caries [1-4]. Streptococcus mutans (S.mutans) is considered to be the principal cariogenic bacterium in humans [5, 6]. It possesses several virulence factors that are associated with its cariogenicity [7]. An essential factor of S.mutans is its sucrose-dependent and glucan-mediated colonization of tooth surfaces. Glucans are

\footnotetext{
* Correspondence: gchaitra.kiran@gmail.com

${ }^{1}$ Department of Pharmaceutical Chemistry, Bharat Institute of Technology,

Mangalpally, JNTUH, R.R. District, Hyderabad, Telangana 501510, India

Full list of author information is available at the end of the article
}

glucose polymers synthesized by extracellular glucosyltransferases (gtfs) [1]. There are three S.mutans gtf's: gtf $\mathrm{B}$ and gtf $\mathrm{C}$ synthesize primarily water-insoluble glucans (WIG) $[8,9]$ and gtf D, synthesize water-soluble glucans (WSG) [10]. Gtfs are involved in many biological processes such as cell-cell communications, signal transduction, immune response, microbial adhesion and infection [11]. Biofilm or dental plaque is formed through two different sequential steps: initial and reversible cell-to-surface attachment and subsequent sucrose-dependent adhesion of the microorganisms, which is firm and irreversible, gtfs are strongly involved in the latter step [12]. There are multiple ways that compounds can exert anticaries action in addition to gtf inhibition. In view of

(c) The Author(s). 2019 Open Access This article is distributed under the terms of the Creative Commons Attribution 4.0 International License (http://creativecommons.org/licenses/by/4.0/), which permits unrestricted use, distribution, and reproduction in any medium, provided you give appropriate credit to the original author(s) and the source, provide a link to the Creative Commons license, and indicate if changes were made. The Creative Commons Public Domain Dedication waiver (http://creativecommons.org/publicdomain/zero/1.0/) applies to the data made available in this article, unless otherwise stated. 
essential roles played by gtfs, intervention of gtfs has attracted remarkable interest among other ways for drug development since inhibitors of gtfs can potentially interfere with the pathological processes [13, 14]. Targeting gtf enzymes prevents the synthesis of extracellular polysaccharides (glucans) and is an attractive strategy for the development of anti-biofilm compounds, as the glucans are extremely important in the processes of biofilm formation and stabilization [15].

The use of medicinal plants or natural products has been one of the most successful strategies for the discovery of new medicines [16]. It already been reported that plant extracts and their components have significant antibacterial activity on oral bacteria, especially on S.mutans [17-21]. Phytochemical rich extracts and their associated compounds have repeatedly shown inhibitory effects against adhesion, plaque and biofilm formation of S.mutans [22-27]. As inhibition of essential virulence factor (gtf) is the primary goal for the prevention of dental carries and possibly other plaque related diseases, present study is aimed to report the anti-caries effects of four plant extracts (Gallnut, Guava, Neem, Indian beech) and two essential oils (Clove oil, Peppermint oil) against S.mutans gtfs.

\section{Material and methods}

Brain Heart Infusion broth (BHI), sucrose, ethanol, sodium dodecyl sulfate, acetic acid, sodium acetate, tween 80, dimethyl formamide (DMF) and ammonium sulfate (all are of analytical grade) were used in the present study and purchased from Merck, Mumbai.

\section{Design of the study}

Four medicinal flora, Terminalia chebula (T.chebula), Psidium guajava (P.guajava), Azadirachta indica (A.indica) and Pongamia pinnata (P.pinnata); two essential oils, clove (Syzygium aromaticum) and peppermint oil (Mentha piperita) were selected as test samples for the present study. By keeping in survey of the folklore use of these plants in dentistry and their reported antibacterial activity [28-31], specific parts of the above mentioned plants like fruits of T.chebula, leaves of P.guajava, twigs of A.indica and P.pinnata were selected. In a similar way essential oils of clove and peppermint were selected as essential oils have stood out as a promising source of bioactive molecules with potential application in the management of dental caries $[32,33]$.

\section{Collection and authentication of plant material}

Fruits of T. chebula (068) were purchased from local commercial market. The leaves of P. guajava (081), twigs of $A$. indica (0125) and P. pinnata (001) were collected from the institutional medicinal garden (cultivated),
Bharat Institute of Technology, Hyderabad. All the collected plant materials were authenticated by Department of Botany, Osmania University, Hyderabad and voucher specimens were submitted in the same place. Clove oil and peppermint oil were procured from essential oil manufacturer (PSC aromatics), Ooty, Tamilnadu.

\section{Preparation of hydroalcoholic extracts of plants}

Plant materials were shade dried and pulverized separately. Each plant material was extracted separately using an equimolar ratio of ethanol and water (50:50) by using a soxhlet extraction method. The hydroalcoholic extracts were concentrated using a rotary evaporator and the dried extracts were preserved at $4{ }^{\circ} \mathrm{C}$ for further use.

\section{Culture collection}

S.mutans MTCC 49 strain used for the present study was facultatively anaerobic, Gram-positive coccusshaped bacterium, procured from the centre for cellular and molecular biology (CCMB), Tarnaka, Hyderabad. A stock of S.mutans MTCC 49 was prepared in glycerol and preserved at $0{ }^{\circ} \mathrm{C}$ until further use.

\section{Production and partial purification of gtf}

A partially purified gtf required for enzyme inhibition studies was prepared according to the modified method of Tomita et.al [34]. BHI broth containing 5\% sucrose was prepared and S.mutans MTCC 49 were inoculated into the media. Furthermore tween $80(1 \mathrm{mg} / \mathrm{ml})$ was incorporated into the media to increase the enzyme production [35]. The inoculated broth was then incubated for $24 \mathrm{~h}$ at $37^{\circ} \mathrm{C}$. Bacteria grown in $600 \mathrm{ml} \mathrm{BHI} \mathrm{broth}$ were centrifuged (1800Xg, $30 \mathrm{~min}$ ) and supernatant fluid obtained was precipitated using $2 / 3$ volume of ammonium sulfate $(60 \%)$. The precipitate was centrifuged and dissolved in $30 \mathrm{ml}$ phosphate buffer ( $\mathrm{pH} 7.4)$ and dialyzed for $24 \mathrm{~h}$ against the same solution. The insoluble material was removed by centrifugation. The dialysate was preserved at $0^{\circ} \mathrm{C}$ until further use.

\section{Determination of cell free gtf activity}

Gtf activity was determined by modified methods of Fukushima et.al [36].

\section{Assay for WIG forming activity (method 1)}

The gtf activity was determined based on the amount of glucans formed, expressed as the absorbance at $340 \mathrm{~nm}$ $\left(\Delta \mathrm{A}_{340} / \mathrm{min}\right)$. The reaction mixture composed of $100 \mu \mathrm{M}$ citrate buffer (pH 6.2), 5\% sucrose, phosphate buffer of $\mathrm{pH} 7.4$ and $0.5 \mathrm{ml}$ of partially purified gtf extract was incubated at $25^{\circ} \mathrm{C}$ for $10 \mathrm{~min}$. The increase in absorbance at $340 \mathrm{~nm}$ was determined using UV-VIS spectrophotometer (Shimadzu 1800). The activity $\left(\Delta \mathrm{A}_{340} / \mathrm{min}\right)$ of 
gtfs was determined from the slope of the linear part of the time course curve.

\section{Calorimetric assay for WIG and WSG forming activity (method 2)}

In this method gtf activity was determined based on the amount of glucans formed, expressed as the glucose content per minute. The reaction mixture composed of $100 \mu \mathrm{M}$ citrate buffer (pH 6.2), 5\% sucrose, phosphate buffer of pH 7.4 (control), $0.5 \mathrm{ml}$ of partially purified gtf extract was incubated at $37^{\circ} \mathrm{C}$ for $2 \mathrm{~h}$. The reaction was terminated by the addition of $0.6 \mathrm{M}$ sodium dodecyl sulfate. WIG pellet was precipitated by centrifugation at 10 , $000 \times \mathrm{g}$ for $5 \mathrm{~min}$. The supernatant was then transferred to another tube and WSG was precipitated with 3 volumes of ethanol at $4{ }^{\circ} \mathrm{C}$ over night. The washed polysaccharide (WIG \& WSG) was quantified based on the glucose content using phenol-sulfuric acid method [37]. For the quantification of WIG and WSG, $50 \mu \mathrm{l}$ of the sample was used in the assay.

\section{Determination of the effect of plant extracts on gtf activity}

The gtf inhibition studies using different concentrations of plant extracts were carried out by method 1. Plant extracts were dissolved in phosphate buffer with gentle heating where necessary and diluted to give final concentrations of $0.312,0.625,1.25,2.5,5$ and $10 \mathrm{mg} / \mathrm{ml}$ in the reaction mixture. The reaction mixture used in the method 1 was incubated replacing phosphate buffer with various concentrations of the plant extracts for $10 \mathrm{~min}$ at $25^{\circ} \mathrm{C}$. The amount of glucan formed was determined according to the procedure described in method 1 . To adjust for the quantification errors due to carbohydrates of plant extracts which will precipitate with the glucans, a parallel series of mixtures without the enzyme was prepared and absorbance value was subtracted from test assay readings.

Determination of the effect of essential oils on gtf activity The effect of essential oils on gtf was determined by method 2 to overcome the solubility problem of essential oils with enzyme solution in method 1 . The two essential oils used in the present study were diluted with DMF separately to make concentrations of $3.125,6.25,12.5$, 25,50 and $100 \mathrm{mg} / \mathrm{ml}$. The reaction mixture used in the method 2 was incubated with various concentrations of the test oils for $2 \mathrm{~h}$ at $37^{\circ} \mathrm{C}$. The amount of WIG and WSG was estimated by the method 2 described above.

\section{Formulation of poly herbal mouth rinse [38]}

The poly herbal mouth rinse formulation was designed based on $\mathrm{IC}_{50}$ values obtained for each plant extract and essential oils (Table 1). It was evaluated for $\mathrm{pH}$ and
Table 1 Formulation of polyherbal mouth rinse

\begin{tabular}{ll}
\hline Ingredients & Working formula \\
\hline T. chebula & $1.091 \mathrm{~W} / \mathrm{v}$ \\
A. indica & $9.262 \mathrm{~W} / \mathrm{v}$ \\
P. guajava & $5.099 \mathrm{~W} / \mathrm{v}$ \\
P. pinnata & $5.63 \mathrm{~W} / \mathrm{v}$ \\
Clove oil & $63.697 \mathrm{~W} / \mathrm{v}$ \\
Peppermint oil & $44.693 \mathrm{~W} / \mathrm{v}$ \\
Ethanol & $6 \mathrm{~V} / \mathrm{v}$ \\
Tween 80 & $3.5 \mathrm{v} / \mathrm{v}$ \\
Distilled water & upto $50 \mathrm{ml}$ \\
\hline
\end{tabular}

clarity test. Finally the effect of mouth rinse against gtf activity was determined and compared with commercial chlorhexidine mouthwash.

\section{Enzyme kinetics}

For kinetic analysis $\mathrm{K}_{\mathrm{M}}$, Vmax and hill coefficient values were measured with non-linear regression analysis using Graphpad Prism 5.0 version.

\section{Statistical analysis}

All the experiments were carried out in triplicates and data was presented as mean \pm SEM. Statistical analysis and enzyme kinetics were performed using Graph pad Prism 5.0 software.

\section{Results and discussion}

The percentage yield of hydro alcoholic extract of T.chebula, P.guajava, A.indica and P.pinnata was found to be $0.480,0.27,0.87$ and $1.177 \% \mathrm{w} / \mathrm{w}$ respectively.

Dental caries is a biofilm-mediated, sugar driven, multifactorial, dynamic disease that results in the phases of demineralization and remineralization of dental hard tissues. The synthesis of extracellular polysaccharide, including WIG \& WSG is one of the most important virulence factors of S.mutans [39]. The WIG promotes the adhesive interactions of bacteria with the tooth surfaces and contributes the formation of dental biofilm [40]. Accordingly, in the present study, we examined whether selected plant extracts inhibits the synthesis of WIG and whether clove and peppermint oils inhibits the synthesis of WSG \& WIG by crude gtfs as there is no previous molecular level mechanistic report on these samples. Our results were in correlation with the literature reports of the anti S.mutans activity of the test samples.

The hydroalcoholic extracts of T.chebula, P.guajava, A.indica and P.pinnata inhibit WIG synthesis by inhibiting S.mutans gtf activity in a dose dependent manner (Table 2). A.indica extract has shown highest percentage inhibition of $91.647 \pm 0.445 \%$ at $10 \mathrm{mg} / \mathrm{ml}$ concentration. Order of gtfs inhibitory activity of the four plant extracts 
Table 2 Gtf inhibitory effect of different plant extracts at various concentrations

\begin{tabular}{lllll}
\hline $\begin{array}{l}\text { Concentration } \\
\mathrm{mg} / \mathrm{ml}\end{array}$ & T.chebula & P.guajava & A.indica & P.pinnata \\
\hline 0.312 & $27.667 \pm$ & $11.300 \pm$ & $5.373 \pm 0.202$ & $7.317 \pm$ \\
& $0.664^{*}$ & 0.529 & & 0.368 \\
0.625 & $50.047 \pm$ & $27.533 \pm$ & $11.887 \pm$ & $18.403 \pm$ \\
& $0.307^{*}$ & 1.210 & 0.873 & 1.291 \\
1.25 & $55.200 \pm$ & $24.610 \pm$ & $22.667 \pm$ & $24.403 \pm$ \\
& $1.159^{*}$ & 2.623 & 0.841 & 1.444 \\
2.5 & $66.530 \pm$ & $28.817 \pm$ & $32.143 \pm$ & $37.260 \pm$ \\
& $1.136^{*}$ & 0.592 & 1.206 & 1.155 \\
5.0 & $77.367 \pm$ & $38.560 \pm$ & $45.067 \pm$ & $44 \pm 2.031$ \\
& $0.939^{*}$ & 0.544 & 0.902 & \\
10 & $83.820 \pm$ & $50.593 \pm$ & $91.647 \pm$ & $77.173 \pm$ \\
& 1.615 & 0.903 & $0.445^{*}$ & 0.817 \\
$R^{2}$ & 0.9673 & 0.8161 & 0.9700 & 0.9412 \\
F-value & 9.487 & 22.55 & 248 & 82.29 \\
IC50 mg/ml & 1.091 & 9.262 & 5.099 & 5.63 \\
\hline
\end{tabular}

Values are expressed in mean \pm SEM and data were analyzed by one way ANOVA at ${ }^{*} p<0.05$

at their highest concentration of $10 \mathrm{mg} / \mathrm{ml}$ was A.indica $>$ T.chebula $>$ P.pinnata $>$ P.guajava. T.chebula extract has shown predominant inhibitory action among tested extracts from 0.312 to $5 \mathrm{mg} / \mathrm{ml}$ (Fig. 1). It means gtf synthesizing WIG from sucrose was almost suppressed upon addition of $10 \mathrm{mg} / \mathrm{ml}$ concentration of A.indica extract. Highest correlation coefficient $\left(\mathrm{R}^{2}\right)$ value is observed with A.indica when compared to other extracts. However, according to the $50 \%$ inhibitory doses $\left(\mathrm{IC}_{50}\right)$ T.chebula would be considered as an effective gtf inhibitor as it has shown effect at lower concentration $(1.091 \mathrm{mg} / \mathrm{ml})$ when compared to other three plant extracts. It has been reported that gtf $\mathrm{B}$ and $\mathrm{C}$ are important factor for synthesis of WIG by S.mutans, gtf B synthesize primary WIG where as gtf $\mathrm{C}$ synthesizes WIG
Table 3 Gtf inhibitory effect of clove and peppermint oils at various concentrations

\begin{tabular}{lll}
\hline Concentration, $\mathrm{mg} / \mathrm{ml}$ & Clove oil & Peppermint oil \\
\hline 3.125 & $2.583 \pm 0.306$ & $7.717 \pm 0.4234$ \\
6.250 & $4.402 \pm 0.234$ & $10.227 \pm 0.127$ \\
12.500 & $7.373 \pm 0.320$ & $13.193 \pm 0.156$ \\
25.000 & $13.8 \pm 0.577$ & $40.567 \pm 0.606$ \\
50.000 & $58.267 \pm 0.960$ & $75.867 \pm 0.606$ \\
100.000 & $70.667 \pm 0.521$ & $88.483 \pm 0.563$ \\
$R^{2}$ & 0.898 & 0.879 \\
$I_{50}$ & 63.697 & 44.693 \\
$F$ & 140.8 & 117.1 \\
\hline
\end{tabular}

Values are expressed in mean \pm SEM

\& WSG [41]. Although we identified that T.chebula, P.guajava, A.indica and P.pinnata extracts may inhibits gtf $B$ by inhibiting WIG synthesis where as clove and peppermint oil inhibits both gtf $\mathrm{B}$ and gtf $\mathrm{C}$ by inhibiting WIG \& WSG synthesis.

To study the molecular level mechanism responsible for the anticaries activity of clove oil and peppermint oil, the effect of these on the WIG \& WSG synthesis by cell free extracellular gtf of S.mutans were examined. Various concentrations ranging from $3.125-100 \mathrm{mg} / \mathrm{ml}$ were used for both the samples and their concentrations are different from that of concentrations used for plant extracts (based on previously reported MIC against S.mutans). Dose dependent inhibition of gtf was observed in both the cases (Table 3) and especially from 25 to $100 \mathrm{mg} / \mathrm{ml}$ there was a drastic increase in \% inhibition. $\mathrm{IC}_{50}$ values of peppermint oil (44.693\%) was significant when compared to clove oil (63.697\%) (Fig. 2). Out of six test samples used in the present study, T.chebula extract has shown the low $\mathrm{IC}_{50}$ value (Fig. 3 ).

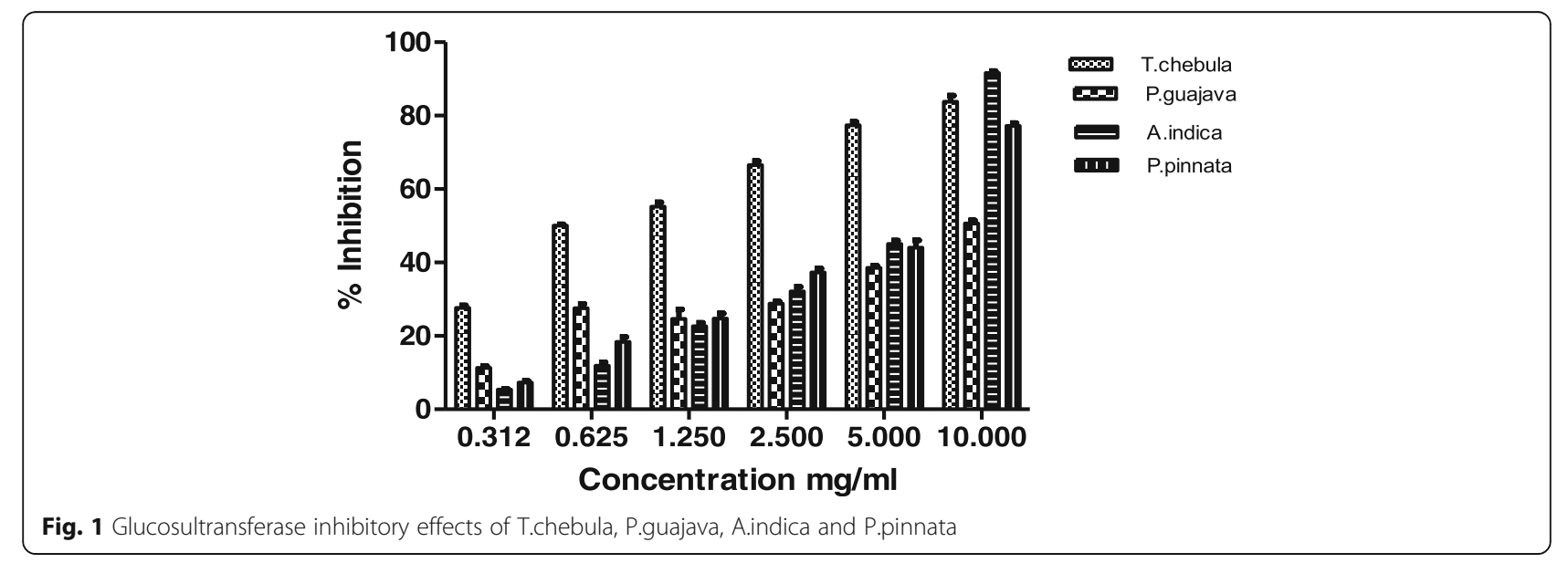




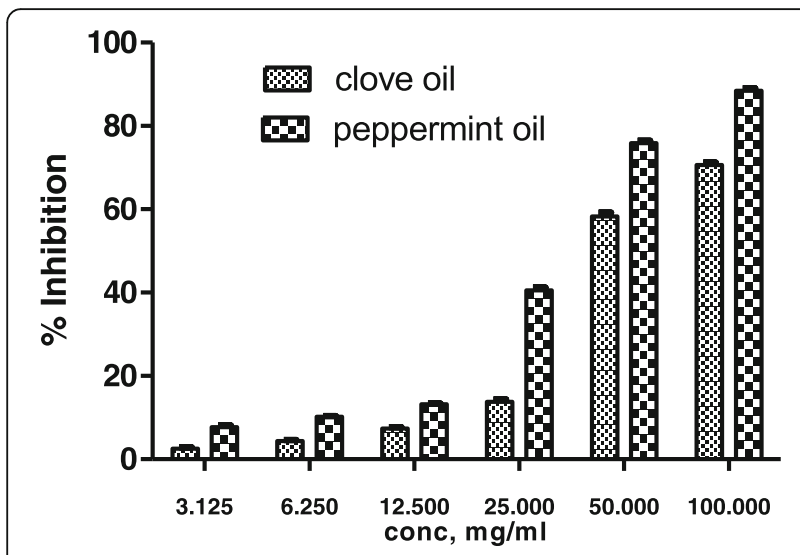

Fig. 2 Gtf inhibitory effects of clove and peppermint oils at various concentrations

$\mathrm{R}^{2}$ value represents square root of the correlation coeffecient and A.indica has $\mathrm{R}^{2}$ value of 0.9700 indicates $0.9700^{2} \times 100(97 \%)$, the higher the percentage better the correlation between results. F-value is a numerical indicator of whether or not the result expressed by the method is coincidental, the higher the value, the less likely the result is due to chance (A.indica has highest Fvalue of 248 among tested extracts).

From kinetic analysis it was observed that T.chebula, P.guajava, A.indica and P.pinnata have shown the exponential curves (Fig. 4) indicative of deviation from normal response (hyperbolic) of the enzyme. From their Michael Menton constant $\left(\mathrm{K}_{\mathrm{M}}\right)$ and Vmax values, it was identified that T.chebula, P.guajava and P.pinnata have shown uncompetitive inhibition as their $K_{M}$ and Vmax values have been decreased when compared to control (without inhibitor). In case of A.indica it was found that

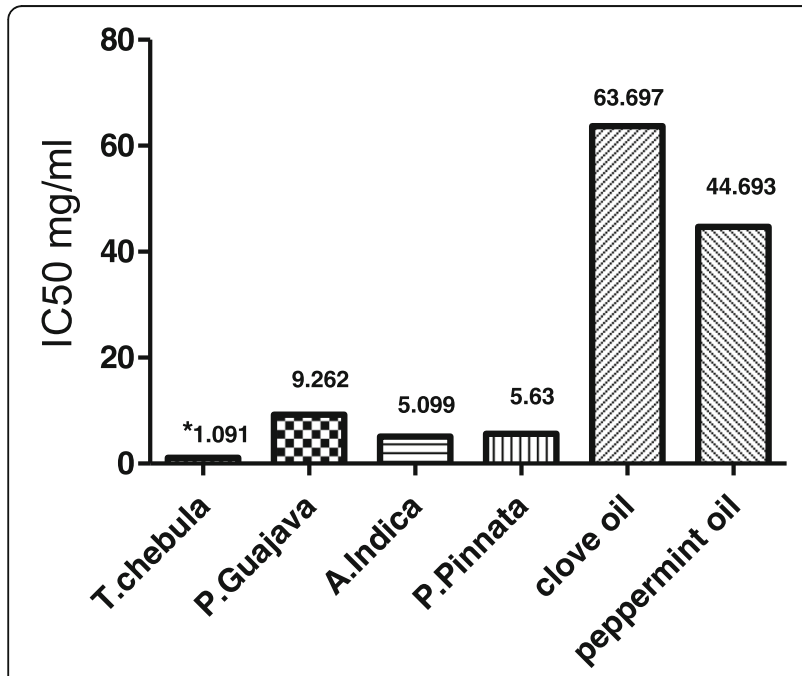

Fig. 3 IC50 values of plant extracts and essential oils

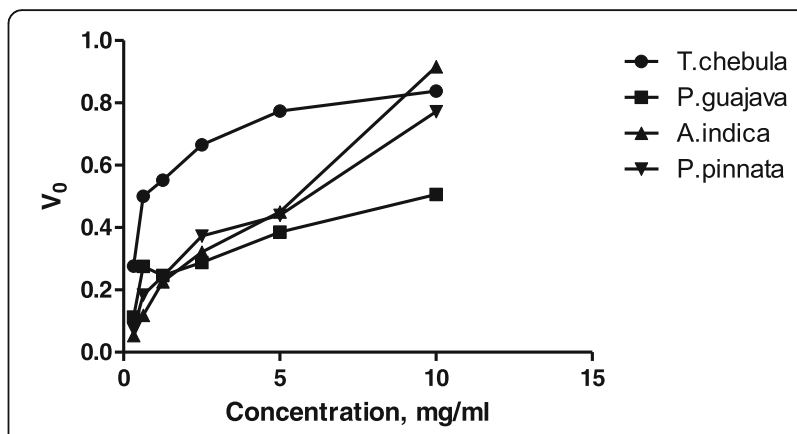

Fig. 4 Exponential response curves of T.chebula, P.guajava, A.indica and P.pinnata extracts

$K_{M}$ unchanged and Vmax decreased indicated that the pattern was of non-competitive inhibition (Table 4).

Similar analyses of clove and peppermint oils revealed the fact that response was sigmoidal and the pattern was of allosteric inhibition (Fig. 5). Sigmoid response curve suggests the cooperativity between the inhibitor and the enzyme and hill coefficient provides a way to quantify the degree of binding between inhibitor and enzyme. Both clove and peppermint oil have shown hill coefficient $>1$ represents positive, cooperative binding (Table 4). Hill coefficient value is more $(4.60 \pm 0.59)$ for clove oil when compared to peppermint oil $(1.92 \pm 0.46)$ indicates that clove oil has more affinity for gtf. The present study mainly focused on the effect of plant extracts and essential oils on gtf inhibition and comparison of the same with commercial anti-carries agent. Here the criteria is to compare molecular level gtf inhibitory mechanism of tested samples so that whether they possess significant anti carries property or not.

The bilologically active phytoconstituents or secondary metabolites present in all four plant extracts have been responsible for their gtf inhibitory activity. Moreover gtf activity of bioactive compounds like tannins [42], flavonoids [43], terpenoids [44] were reported previously. The tannins in T.chebula fruits, terpenoids in A.indica twigs, isoflavones in twigs of P.pinnata and flavonoids and tannins present in leaves of P.guajava may be the attributing factors for S.mutans gtf inhibition.

The antibacterial properties of plant essential oils against bacteria found in the oral cavity are also well documented [45]. While the commercial mouthwashes

Table 4 Kinetic parameters of the inhibitory effect of test samples on the activity of gtf

\begin{tabular}{|c|c|c|c|c|c|c|c|}
\hline & Control & T.chebula & P.guajava & A.indica & P.pinnata & $\begin{array}{l}\text { Clove } \\
\text { oil }\end{array}$ & $\begin{array}{l}\text { Peppermint } \\
\text { oil }\end{array}$ \\
\hline$K_{M}$ & 21.30 & 0.6115 & 1.006 & 20.82 & 5.101 & 211.20 & 73.64 \\
\hline$V_{\max }$ & 25.9 & 3.695 & 6.940 & 13.74 & 23.16 & 231.21 & 161.41 \\
\hline $\begin{array}{l}\text { Hill } \\
\text { coefficient }\end{array}$ & NA & NA & NA & NA & NA & $\begin{array}{l}4.60 \pm \\
0.59\end{array}$ & $1.92 \pm 0.46$ \\
\hline
\end{tabular}




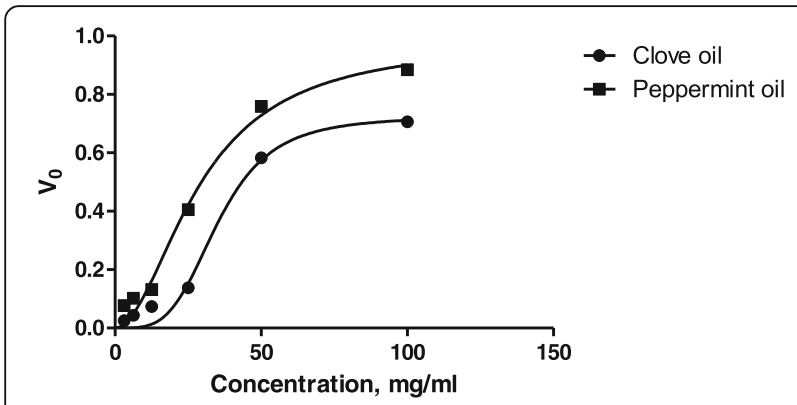

Fig. 5 Sigmoidal response curves of clove oil and peppermint oil

containing essential oils are useful in the long-term control of plaque and mild to moderate gingivitis and are preferred to use in chlorhexidine containing mouth washes for long-term daily use [46]. Therefore, essential oils may be suitable additives in pharmaceutical products.

There has been reports about the menthol present in Mentha piperata (peppermint oil) and eugenol in Syzygium aromaticum (clove oil) and are considered as outstanding compounds exhibiting an antibacterial potential [47] which could be responsible for S.mutans gtf inhibition.

The present study also focused on the formulation of the polyherbal mouth rinse and its $\mathrm{IC}_{50}$ value was found to be $7.938 \% \mathrm{w} / \mathrm{v}$. The $\%$ inhibition at its maximum concentration of $15 \% \mathrm{w} / \mathrm{v}$ was found to be $95.936 \pm 1.518$ and it was very high when compared to $53.80 \pm 1.83 \%$ inhibition of chlorohexidine commercial mouthwash. Dose dependent gtf inhibitory effect was observed in case of polyherbal mouth wash and chlorhexidine did not follow this pattern. From the results it was observed that gtf inhibitory potential of the polyherbal mouth rinse was significant $(p<0.05)$ compared to chlorhexidine mouthwash at tested concentrations (Fig. 6). From the shape of the exponential curve (concentration of



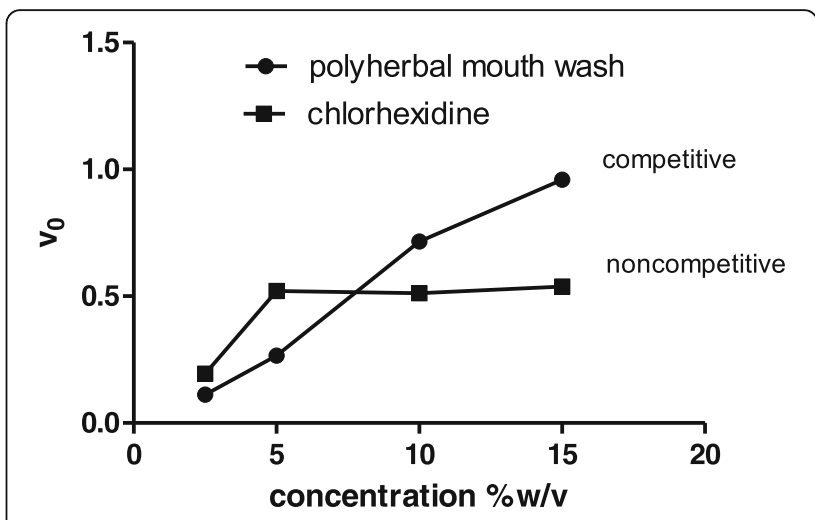

Fig. 7 Exponential response curves of Polyherbal mouth rinse and Chlorhexidine mouth

inhibitor vs enzyme velocity) it was evident that polyherbal mouth rinse competitively inhibits gtf where as chlorhexidine shows non-competitive inhibition (Fig. 7).

\section{Conclusions}

From the studies it was concluded that among the four plant extracts and two essential oils tested against gtf activity A.indica extract has shown maximum percentage inhibition and T.chebula extract has shown the significant $\mathrm{IC}_{50}$ value when compared to others. The results of kinetic analysis proposed that T.chebula, P.guajava, P.pinnata have shown uncompetitive gtf inhibition where as A.indica has shown non-competitive inhibition. Clove oil and Peppermint oil have proposed allosteric inhibition and the standard chlorhexidine has shown noncompetitive inhibition. Moreover the polyherbal mouth rinse prepared from all four plant extracts and two essential oils has shown predominant gtf inhibition (95.936\%) when compared to $54 \%$ shown by chlorohexidine mouthwash. Further clinical investigations are recommended for this polyherbal mouth rinse to utilize as anticaries agent.

\section{Abbreviations}

A.indica: Azadirachta indica; $\mathrm{BH}$ broth: Brain heart infusion broth; DMF: Dimethyl formamide; Gtfs: Glucosyltransferases; MIC: Minimum inhibitory concentration; P.guajava: Psidium guajava; P.pinnata: Pongamia pinnata; S.mutans: streptococcus mutans; T. chebula: Terminalia chebula; WIG: Water insoluble glucans; WSG: Water soluble glucans

\footnotetext{
Acknowledgements

Authors are thankful to Sri C. Venugopal Reddy, Secretary, Bharat Institutions and Dr. Sudheer B, ICT, Hyderabad for their kind help and constant encouragement towards this research.

\section{Declaration}

The experimental work described in this article was conducted in the Bharat institute of technology, Department of Pharmaceutical Chemistry and Pharmaceutical Biotechnology, Hyderabad, India, from December 2016 to May 2017. These studies are the result of our own investigations, except where the work of others is acknowledged and have not been submitted in any other form to another journal.
} 


\section{Authors' contributions}

KM and BUR designed and reviewed the research and wrote the paper, SK, SR, ICH and BS conducted the research, NS edited the analytical work. All authors read and approved the final manuscript.

\section{Funding}

These analyses were done with self-funding.

\section{Availability of data and materials}

All data and materials used in this research are available from the corresponding author on reasonable request.

\section{Ethics approval and consent to participate}

Not applicable.

\section{Competing interests}

The authors declare that they have no competing interests.

\section{Author details}

'Department of Pharmaceutical Chemistry, Bharat Institute of Technology, Mangalpally, JNTUH, R.R. District, Hyderabad, Telangana 501510, India. ${ }^{2}$ Department of Pharmaceutical Biotechnology, Bharat Institute of Technology, Mangalpally, JNTUH, R.R. District, Hyderabad 501510, India.

Received: 14 September 2017 Accepted: 23 July 2019

Published online: 02 August 2019

\section{References}

1. Mundorff SA. Bibby BG cariogenic potential of food. Caries Res. 1990;24: 344-9.

2. Clarkson BH. Introduction to cariology: the discipline of cariology; art or science dent. Clin North Am. 1999;43(4):569-77.

3. Baneriee A, Watson TF, Kidd EAM. Dentin caries: take it or leave it? Dent Update. 2000;27:272-6.

4. Ramya R, Srinivasan R. Clinical operational dentistry, principles and practice. $1^{\text {st }}$ ed. EMM ESS Medical Publishers; 2007.

5. Loesche WJ. Role of Streptococcus mutans in human dental decay. Microbial Rev. 1986;50:353-80.

6. Tanzer JM, Livingston J, Thompson AM. The microbiology of primary dental carries in humans. J Dent Educ. 2001;65:1028-37.

7. Banas JA. Virulence properties of Streptococcus mutans. Front Biosci. 2004;9: $1267-77$.

8. Aoki H, Shiroza T, Hayakawa M, Sato S, Kuramitsu HK. Cloning of a Streptococcus mutans glucosyltransferases gene, coding for insoluble glucan synthesis. Infect Immun. 1986;53:587-94.

9. Hanada N, Kuamitsu HK. Isolation and characterization of the Streptococcus mutans gtf $\mathrm{C}$ gene, coding for synthesis of both soluble and insoluble glucans. Infect Immun. 1988;56:1999-2005.

10. Hanada N, Kuamitsu HK. Isolation and characterization of the Streptococcus mutans gtf $\mathrm{D}$ gene, coding for primer dependent soluble glucan synthesis. Infect Immun. 1989;57:2079-85.

11. Varki A, Cummings RD, Esko JD, Freeze HH, Stanley P. Essentials of glycobiology. $2^{\text {nd }}$ ed. Cold spring harbor (NY): Cold spring harbor laboratory press; 2009.

12. Kawabata S, Hamada S. Studying biofilm formation of mutans streptococci: Mthods in enzymology 1999:30:513-523.

13. Gloster TM, Vocadlo DJ. Developing inhibitors of glycan processing enzymes as tools for enabling glycobiology. Nat Chem Biol. 2012;8:683-94.

14. Wagner GK, Pesnol T. Glucosyltransferases and their assays. Chembiochem. 2010;11:1939-49

15. Branda SS, Vik S, Friedman L, Kolter R. Biofilms: the matrix revisited. Trends Microbiol. 2005;13:20-6.

16. Harvey A. Strategies for discovering drugs from previously unexplored natural products. Drug Discov Today. 2000;5:294-300.

17. Namba T, Tsunezuka M, Dissanayake DMRB, Pilapitiya U. Saikok, Kakiuchi N, Hattori M. studies on dental caries prevention by traditional medicines part VII. Screening of ayurvedic medicines for anti-plaque action. Shoyakugoku Zasshi. 1985:39(2):146-53.

18. Chen CP, Lin CC, Namba T. Screening of Taiwanese crude drugs for antibacterial activity against Streptococcus mutans. Ethanopharm. 1989;27: 285-95.
19. Saeki Y, Ito Y, Shibata M, Sato Y, Okuda K, Takazoe I. Antimicrobial action of natural substances on oral bacteria. Bull Tokoyo Dent Coll. 1989:30(3):129-35.

20. Osawa K, Matsumoto T, Maruyama J, Takiguchi T, Okuda K, Takazoe T. Studies of the antibacterial activity of plant extracts and their constituents against periodonpatho bacteria. Bull Tokyo Dent Coll. 1990;31(1):1721.

21. Yamaki M, Kashihara M, Takagi S. Activity of Ku Shen compounds against Streptococcus aureus and Streptococcus mutans. Phytother Res. 1991;4(6): 235-6.

22. Nostro A, Cannatelli MA, Crisafi G, Musolino AD, Procopio Alonzo V. Modifications of hydrophobicity, in vitro adherence and cellular aggregation of Streptococcus mutans by Helichrysum italicum extract. LAM Lett Appl Microbiol. 2004;38:423-7.

23. Yamanaka A, Kimizuka R, Kato T, Okuda K. Inhibitory effects of cranberry juice on attachment of oral streptococci and biofilm formation. Oral Microbiol Immunol. 2004:19:150-4.

24. Percival RS, Devine DA, Duggal MS, Chartron S, Marsh PD. The effect of cocoa polyphenols on the growth, metabolism, and biofilm formation by Streptococcus mutans and Streptococcus sanguinis. EOS Eur J Oral Sci. 2006;114:343-8.

25. Furiga A, Lonvaud Funel A, Dorignac $G$, Badet C. In vitro anti-bacterial and anti-adherence effects of natural polyphenolic compounds on oral bacteria. JAM J Appl Microbiol. 2008;105:1470-6.

26. Rahim ZHA, Khan HBSG. Comparative studies on the effect of crude aqueous (ca) and solvent $(\mathrm{cm})$ extracts of clove on the cariogenic properties of Streptococcus mutans. J Oral Sci. 2006;48:117-23.

27. Matsumoto M, Tsuji M, Okuda J, Sasaki H, Nakano K, Osawa K, Shimura S, Ooshima T. Inhibitory effects of cacao bean husk extract on plaque formation in vitro and in vivo. Eur J Oral Sci. 2004;112:249-52.

28. Nayak SS, Ankola AV, Metgud SC, Bolmal UK. An in vitro study to determine the effect of Terminalia chebula extract and its formulation on Streptococcus mutans. J Contemp Dent Prac. 2014;15(3):278-82.

29. Garode AM, Waghode SM. Antibacterial activity of guava leaves extracts against S.mutans. Inter J Bioassays. 2014;3(10):3370-2.

30. Lakshmi T, Krishnan V, Rajendran R, Madhusudhanan N. Azadirachta indica: a herbal panacea in dentistry-an update. Pharmacogn Rev. 2015;9(17):41-4.

31. Imran M, Bashir S, Sher M, Shah HS, labal S, Asad M. Anticariogenic activity, possible mechanism and preliminary characterization of twigs of Pongamia pinnata. J Pharm Sci Pharmacol. 2015:2(1):57-63.

32. Lang G, Buchbauer GA. A review on recent research results (2008-2010) on essential oils as antimicrobials and antifungals. A review. Flavour Fragr J. 2012;27:13-39

33. Lobo PL, Fonteles CS, Marques LA, Jamacaru FV, Fonseca SG, De Carvalho CB, De Movaes ME. The efficacy of three formulations of lippie sicloides Cham essential oil in the reduction of salivary Streptococcus mutans in children with caries: a randomized double blind, controlled study. Phytomed. 2014;21:1043-7.

34. Tomita Y, Zhu X, Ochiai K, Namiki Y, Okada T, Ikemi T, Fukushima K. Evaluation of three individual glucosyl transferases produced by streptococcus mutans using monoclonal antibodies. FEMS Microbial Lett. 1996;145:427-32.

35. Umesaki Y, ${ }^{*}$ Kawai $Y$, Mutai M. Effect of tween 80 on glucosyltransferase production in Streptococcus mutans App Env Microbiol. 1977;3(2):115-119.

36. Fukushima K, Motoda R, Takada K, Ikeda T. Resolution of Streptococcus mutans glycosyltransferases into two components essential to waterinsoluble glucan synthesis. FEBS Lett. 1981;128:213-6.

37. Dubo's M, Gilles A, Hamilton JK, Rebers PA, Smith F. Colorimetric method for determination of sugars and related substances. Ann N Y Acad Sci. 1956: 121:404-27.

38. Chiedozie El, Ahamefule OF, Ukamaka AA. Anti-inflammatory, antimicrobial and stability studies of poly-herbal mouthwashes against Streptococcus mutans. J Pharmacog Phytochem. 2016;5(5):354-61.

39. Schilling KM, Bowen WH. Glucans synthesized in situ in experimental salivary pellicle formation as specific binding sites for Streptococcus mutans. Infect Immun. 1992:60:284-95.

40. Madisan KM, Bowen WH, Pearson SK, Falany JL. Enhancing the virulence of S.sorbinus in rats. J Dent Res. 1991;70:38-43.

41. Yamachita Y, Bowen WH, Burne RA, Kuramitsu HK. Role of the S.mutans gtf genes in caries induction in the specific- pathogen-free rat model. Infect Immun. 1993;61:3811-7.

42. kakiuchi N, Hattori m, Nizhizawa M, Yamagishi T, kuda T, Namba IAT. Studies on dental caries prevention by traditional medicines VIII inhibitory effect of 
various tannins on glucan synthesis by glucosyltransferase from Streptococcus mutans. Chem Pharm Bull. 1986;34(2):720-5.

43. Hyunk O, Pedro L. Rosalen, William H, Bowen. Effects of compounds found in propolis on S.mutans growth and on glucosyl transferase activity. Antimicrob Agents Chemother. 2002;46(5):1302-9.

44. William H. Bowen, Hyun Koo, Yong kun park, Jaime a parecido Cury, Pedroluiz Rosalen. University of Rochester, Universidade Estadual De compinas WO 2002047615 A2; 2002.

45. Kalemba D, Kunicka A. Antibacterial and antifungal properties of essentialoils. Cur Med Chem. 2003;10(10):813-29.

46. Ciancio IS. Improving oral health: Current considerations. J Clin Periodont. 2003;30(3):4-6.

47. Freires IA, Denny C, Benso B, de Alencar SI, Rosalen P. Antibacterial activity of essential oils and their isolated constituents against cariogenic bacteria: a systematic review. Molecules. 2015;20:7329-73.

\section{Publisher's Note}

Springer Nature remains neutral with regard to jurisdictional claims in published maps and institutional affiliations.

Ready to submit your research? Choose BMC and benefit from:

- fast, convenient online submission

- thorough peer review by experienced researchers in your field

- rapid publication on acceptance

- support for research data, including large and complex data types

- gold Open Access which fosters wider collaboration and increased citations

- maximum visibility for your research: over $100 \mathrm{M}$ website views per year

At BMC, research is always in progress.

Learn more biomedcentral.com/submissions 